Chapter 19

\title{
Environmentally Friendly Corrosion Inhibitors
}

\author{
Rafael Martinez Palou, Octavio Olivares-Xomelt and \\ Natalya $\mathrm{V}$. Likhanova \\ Additional information is available at the end of the chapter \\ http://dx.doi.org/10.5772/57252
}

\section{Introduction}

In most industries whose facilities are constituted by metallic structures, the phenomenon of corrosion is invariably present. This problem originates very important material and economic losses due to partial or total replacement of equipment and structures, and plant-repairing shutdowns.

Material losses and corrosion consequences are priced so high that in some countries like the U.S. and England these factors have been estimated from 3 to $4 \%$ of the GDP.

Corrosion not only has economic implications, but also social and these engage the safety and health of people either working in industries or living in nearby towns. The oil industry in Mexico is one of the most affected by corrosion because this phenomenon exerts its effects from the very moment of oil extraction on, causing a constant struggle against it.

The use of corrosion inhibitors (CIs) constitutes one of the most economical ways to mitigate the corrosion rate, protect metal surfaces against corrosion and preserve industrial facilities $[1,2]$.

Inorganic CIs are those in which the active substance is an inorganic compound. This is one of the simplest ways to improve the passivity of a metal by adding electropositive metal salts to the medium. These metal ions must have a more positive redox potential more positive than the metal constituting the surface to be protected and also a more positive potential than that required for discharging a proton so that the electropositive metal to be reduced is deposited on the surface.

The deposited metal promotes the cathodic depolarization by overvoltage reduction and formation of an adherent deposit. Among the metals used for this purpose are: mercury ( $\mathrm{Hg})$, palladium $(\mathrm{Pd})$, iridium (Ir), platinum $(\mathrm{Pt})$, rhodium $(\mathrm{Rh})$ and rhenium $(\mathrm{Re})$. 
Moreover, there are inorganic anions providing passivation protection to metal surfaces through their incorporation into the oxide layer; the most widely used of these are: chromate $\left(\mathrm{CrO}_{4}{ }^{2-}\right)$, nitrate $\left(\mathrm{NO}_{2}^{-}\right)$, molybdate $\left(\mathrm{MoO}_{3}^{-}\right)$, phosphate $\left(\mathrm{H}_{2} \mathrm{PO}_{3}^{-}\right)$and silicates [3].

Organic inhibitors have been the most widely used in petroleum refining processes because of their ability to form a protective layer on the metal surface in media with high hydrocarbons content. At present there are a number of organic inhibitors belonging to different chemical families i.e. fatty amides [4, 5], pyridines [6-8], imidazolines [9-12] and other 1,3-azoles [13-15] and polymers [16] have showed excellent performance as CIs (Table 1) [17].

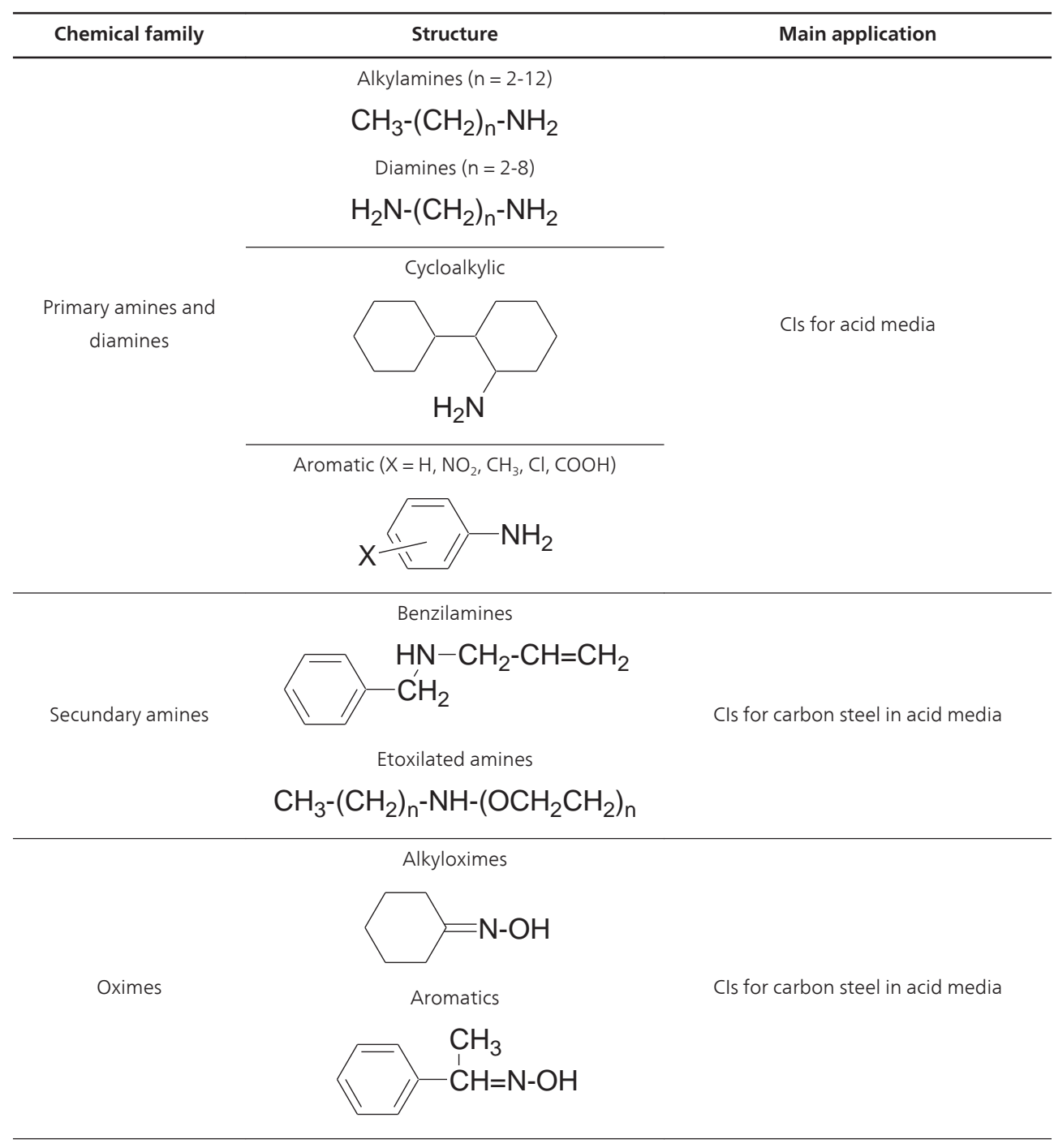




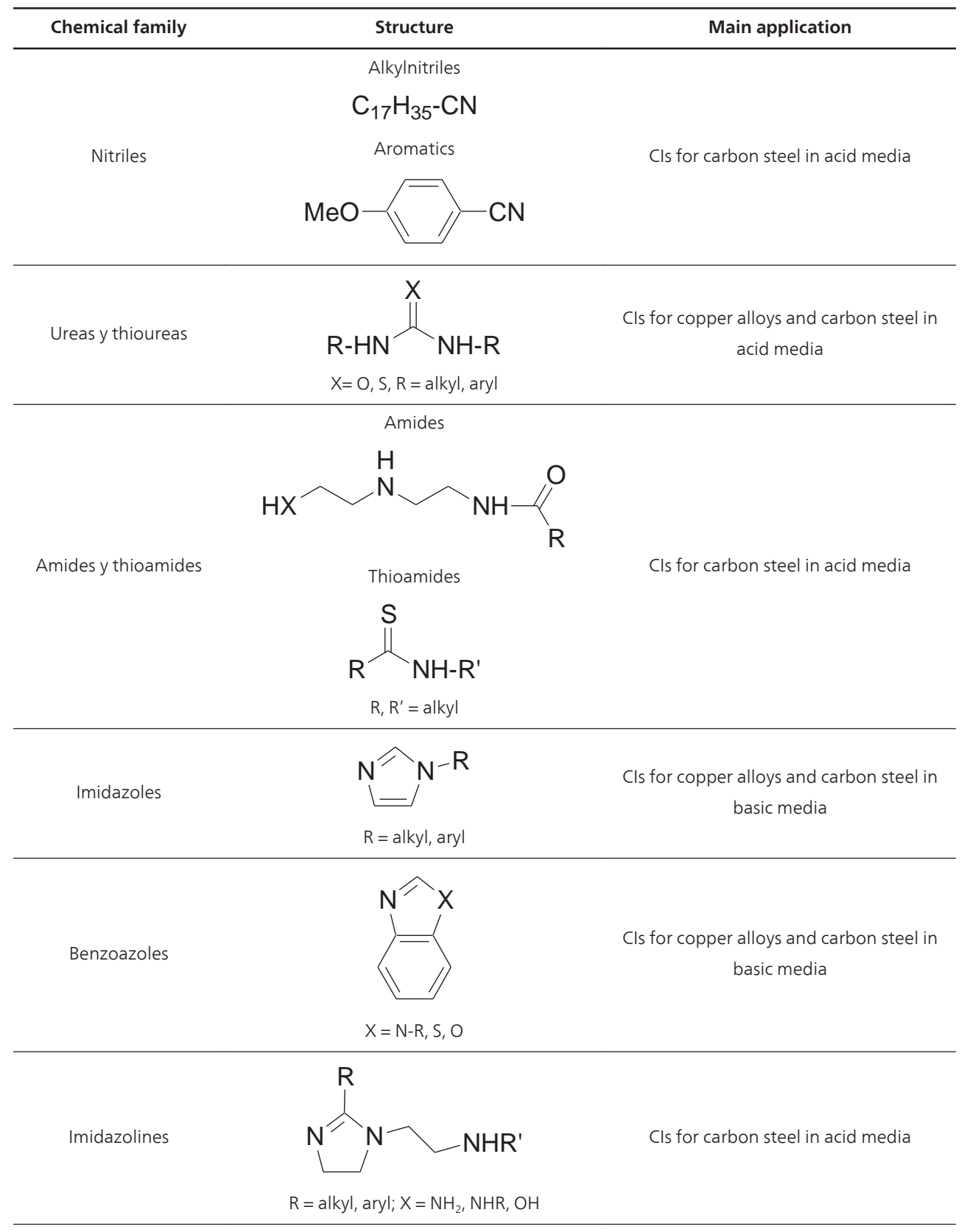




\begin{tabular}{ccc}
\hline Chemical family & Main application \\
\hline Pyridines & Cls for carbon steel in acid media \\
\hline Triazoles & \\
\hline Penzotriazoles & \\
\hline
\end{tabular}

Table 1. Organic corrosion inhibitors widely used in petroleum refining processes

The aim of adding inhibitors in low concentrations to corrosive media is to delay the reaction between the metal and the corrosive species in the medium. CIs act by adsorbing either ions or molecules onto the metal surface, generally reducing the corrosion rate by blocking the anodic and/or cathodic reactions.

In spite of much inorganic, organic and polymeric compounds have been showed good performances as CIs for different metals and alloys, many of these compounds are toxic and do not fulfill completely the requirements imposed by the environmental protection standards. The new generation of environmental regulations requires the replacement of toxic chemicals with the so-called "Green chemicals". The final choice of the inhibitor for a particular application is restricted by several factors, including increased environmental awareness and the need 
to promote environmentally friendly processes, coupled with the specificity of action of most acid inhibitors, which often requires the combined action of compounds to achieve effective corrosion inhibition. This is the reason why in the last years big efforts have been made by researchers in this area to develop new environmentally friendly CIs (EFCIs).

In this chapter, generalities about the corrosion phenomena and CIs are presented and a review of research papers describing the development of novel EFCIs, both natural and synthetic, for several corrosive environments and different metals and alloys are discussed in detail, especially for the applications in the Oil Industry.

\section{Generalities about corrosion [2]}

The term corrosion can be defined as the interaction (electrochemical reaction) of a metal with the surrounding environment, causing a slow, steady, and irreversible deterioration in the metal, in both physical and chemical properties.

The corrosion causes very important material and economical losses due to partial or total replacement of equipment and structures, and plant-repairing shutdowns.

Corrosion not only has economic implications, but also social and these engage the safety and health of people either working in industries or living in nearby towns. The petroleum industry is one of the most affected by corrosion due to the presence of many corrosive substances in the crude oil, which affect equipments and pipelines from the extraction of crude oil to the transportation of final products.

The factors that can cause corrosion can be identified as:

- Physical

- Chemical

- Electrochemical

- Microbiological

Physical corrosion is caused by impact, stress or exhaustion of the material. Chemical corrosion is caused by oxygen, sulfur, fluorine, chlorine or other gases, which act directly on the metal under environmental conditions that facilitate this phenomenon. Electrochemical corrosion is a spontaneous process that denotes the existence of anodic and cathodic zones, and an electrolyte; electrical contact between the anodic and cathodic zones is also required (Figure 1).

Microbiological corrosion is the deterioration of a metal that occurs directly or indirectly as a result of the activity of microorganisms such as bacteria and algae. These microorganisms are deposited on the metal, creating a "live" area, using nitrogen, oxygen, hydrogen, and/or carbon from the environment for their metabolic activities, producing metabolites, which can be deposited on the metal promoting corrosion. Biological activity may cause corrosion in a variety of media such as natural water, sea water, petroleum products and oil emulsions. 


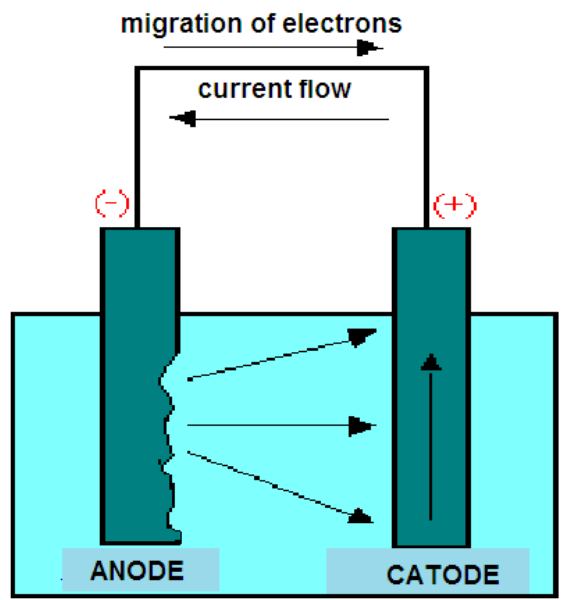

Figure 1. Representation of electrochemical corrosion.

According to the environment to which materials are exposed, there are various forms of corrosion: uniform or general, bite, erosion, stress, cavitation, galvanic and hydrogen embrittlement-blistering. Knowing how corrosion works helps to understand the phenomenon and provide possible solutions to counter the corrosive process.

a. Uniform or general corrosion is the most common, which is characterized by the fact that corrosion occurs uniformly over the metal surface and has a high corrosion rate; the loss of the metal surface occurs through an anodic site, and the appearance of the corroded surface is relatively uniform, but manifests roughness (Figure 2) [18].

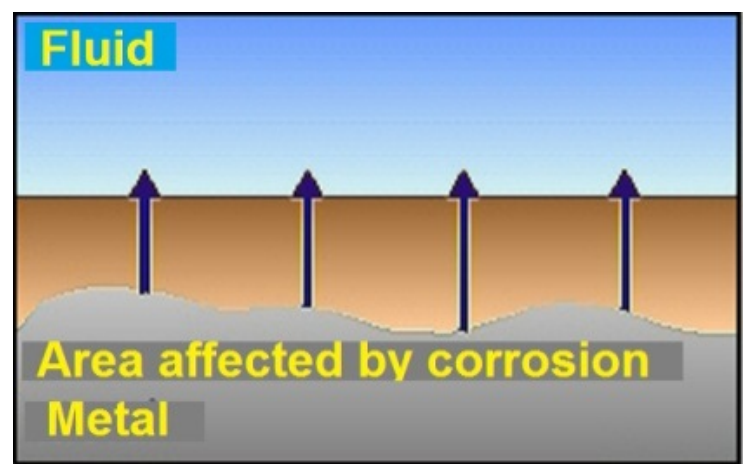

Figure 2. Uniform Corrosion

b. Pitting corrosion: Is a localized attack, where some parts of the metal surface are free of corrosion, but small localized areas are corrode quickly; this occurs when any solid 


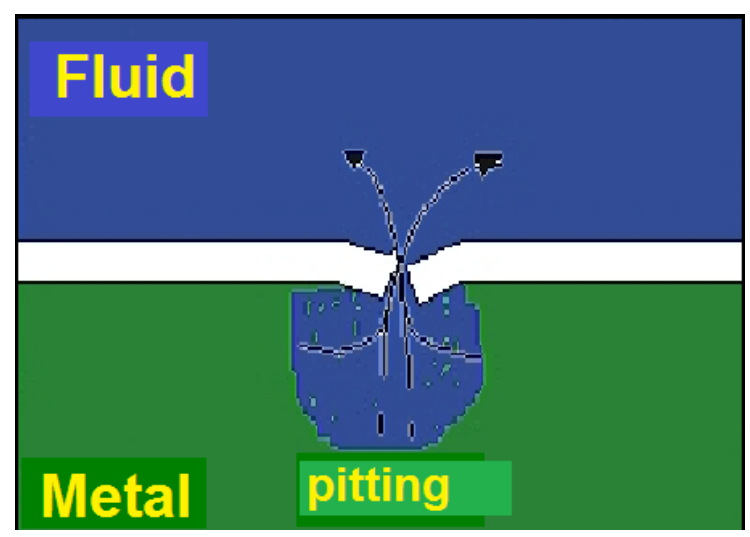

Figure 3. Pitting corrosion.

corrosion product or neutralization salts are located on the metal surface, causing deep holes, which is known as pitting (Figure 3); these areas are the most susceptible to the corrosion process [19].

c. Corrosion by erosion: This type of corrosion provokes uniform thinning of the metal surface, which is associated with the exposure to a high velocity fluid, which causes the corrosion product to be stripped from the metal surface, resulting in the exposure of the bare metal, which can be corroded again, causing an accelerated attack, (Figure 4). This type of corrosion is further exacerbated when fluids contain solid particles that are harder than the metal surface, which hit constantly the metal [20].

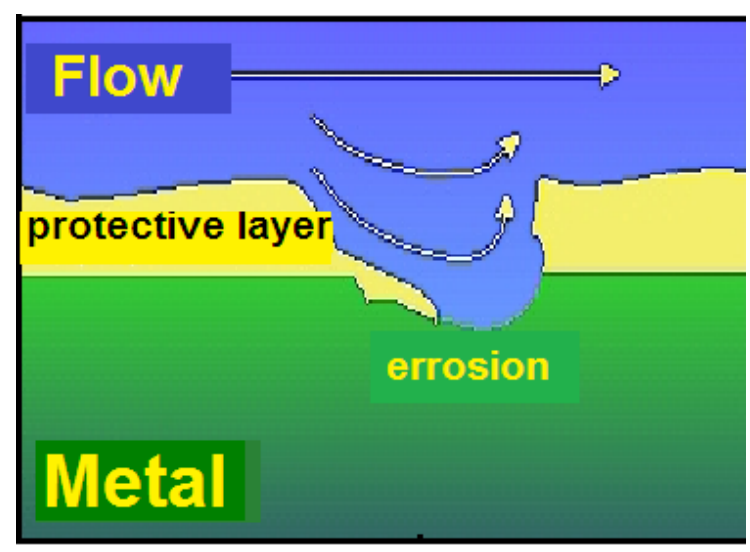

Figure 4. Corrosion by erosion 
d. Stress corrosion cracking: This type of corrosion promotes the formation of a fracture in the metal structure due to mechanical stress and a chemically aggressive medium (Figure 5) [21].

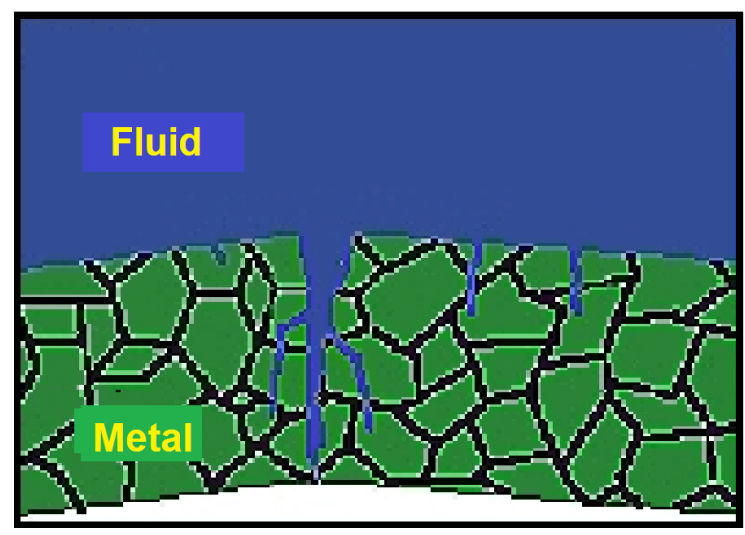

Figure 5. Stress corrosion cracking

e. Galvanic or bimetallic corrosion occurs when there is a potential difference between dissimilar metals immersed in a corrosive solution; the potential difference produces a flow of electrons between the metals, where the less resistant metal is the anode (metal active), and the most resistant is the cathode (noble metal). This attack can be extremely destructive, dramatically accelerating the corrosion rate of the most reactive metal, but the severity degree of galvanic corrosion depends not only on the potential difference between the two metals, but also on the involved surface area ratios, (Figure 6) [22].

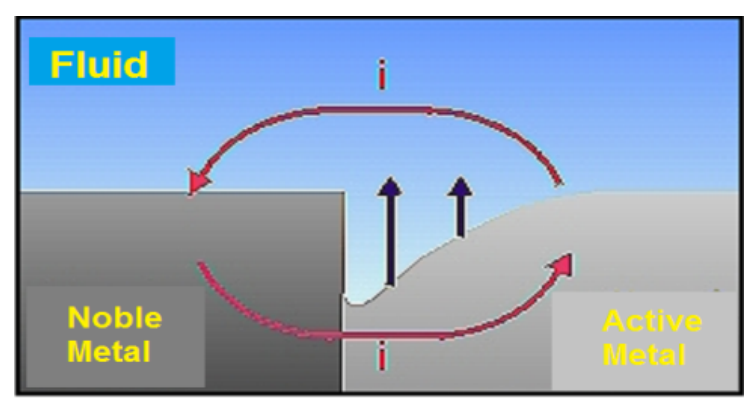

Figure 6. Galvanic corrosion

f. Corrosion by cavitation is a form of erosion caused by the formation and rupture of vapor bubbles in the fluid near the metal surface, causing a sequence of pits in the form of small, but deep cracks (Figure 7) [23]. 


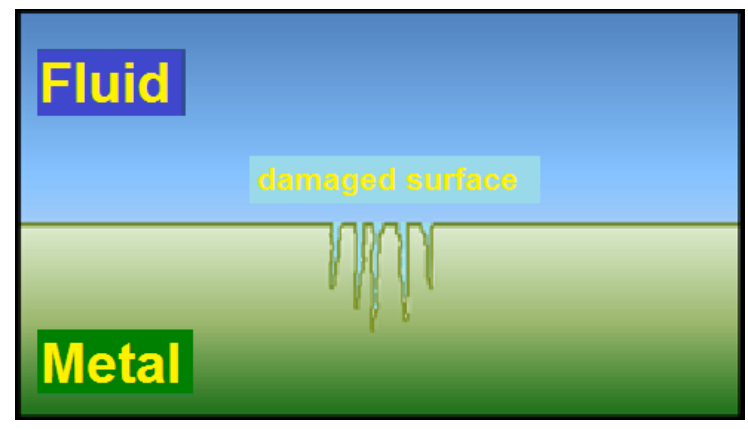

Figure 7. Corrosion by cavitation

g. Corrosion via hydrogen embrittlement and blistering is associated with the hydrogen atoms that are produced on the metal surface in an aqueous medium; a reduction reaction when atomic hydrogen penetrates the metal takes place; the presence of defects allow the interaction between the hydrogen atoms and the metal, forming molecular hydrogen, which being trapped by the metal, provides enough pressure to form blisters, resulting in microcracks, (Figure 8). This type of failure occurs mainly in basic media, where there are compounds such as sulfides and/or cyanides; this corrosion process is also present in plants with catalytic refining processes.

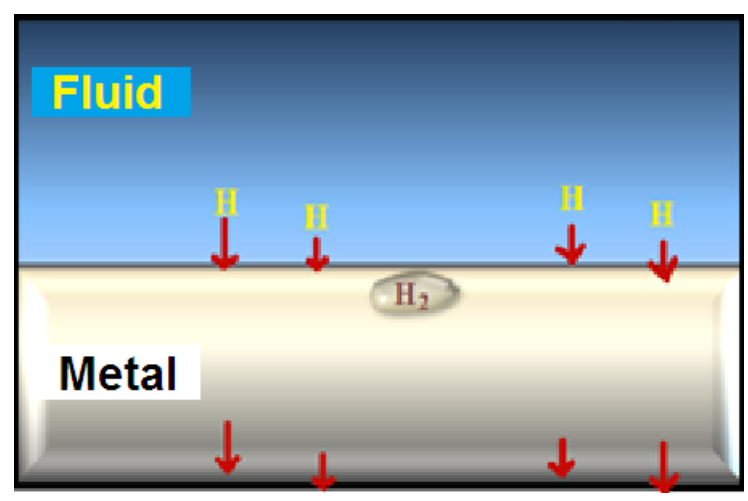

Figure 8. Corrosion by hydrogen embrittlement and blistering.

In this kind of corrosion process, some hydrogen atoms diffuse through steel and become retained, where they recombine with each other, forming a very strong internal pressure that exceeds the strength of steel, forming blisters.

In most oil refining plants, the reactive metal is iron, which is the major component of the steel present in pipelines and equipment; the electrolyte is water and the corrosive or oxidizing agent is formed by acids, salts, bases, oxygen, etc. One of the most common methods used to 
reduce corrosion in petroleum refining processes is the application of corrosion inhibitors, which are specific for each process phase, medium and corrosion type [24].

\section{Corrosion control [25]}

In order to control some of the corrosion problems, several preventive measures are taken:

a. Cathodic protection. This is an effective method to control corrosion on structures either buried or immersed in an electrolyte; according to the operation mode, anodes are classified as impressed current and sacrificial.

b. Protection with anticorrosive coating. This is mainly used to form a physical barrier between the corrosive environments to protect the structure. It is used mainly with metallic elements exposed to the atmosphere.

c. Corrosion Inhibitors. These are substances that added in small concentrations (parts per million, ppm) to a corrosive environment decrease the corrosion rate effectively. This method has its main application in the interiors of pipelines, vessels and equipments.

A corrosion inhibition program should be monitored continuously to ensure that it is achieving the desired protection.

The corrosion measurement is the quantitative method by which we know the effectiveness of the control that is being carried out, and provides feedback that makes possible to optimize the control and corrosion prevention methods.

Particularly in the Petroleum Industry, the monitoring can be done by using the following methods:

- Monitoring feedstocks by chemical analysis to find some of their features and corrosive contents.

- Monitoring corrosives by analysis of bitter waters of batteries ( $\mathrm{pH}$, chlorides, sulfides, ammonium thiocyanate and cyanide).

- Corrosion Monitoring: Be made in the following ways:

a. Using gravimetric coupons located at places where corrosion is to be measured (Figure 9).

b. With corrosimetric specimens. These probes are installed at the places to be monitored. A corrosometer connected to a probe detects a current amount and depending on it, it is known if there is corrosion and the communication speed.

c. Analyzing the iron and copper contents in the bitter waters of accumulators.

d. By placing hydrogen probes at the absorber tower. 


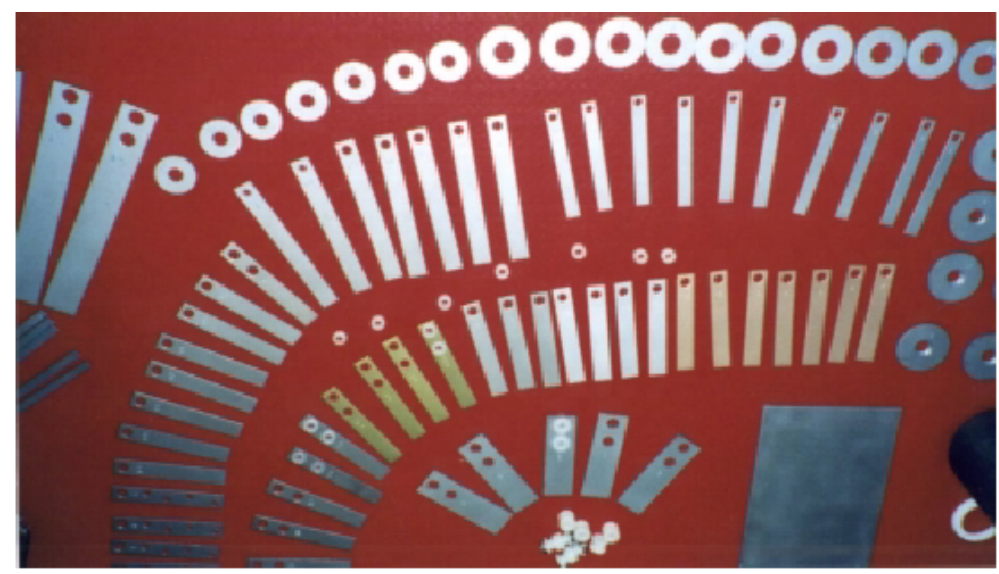

Figure 9. Coupons to measure corrosion.

\section{Corrosion Inhibitors (CIs)}

CIs are either organic or inorganic chemicals, or more commonly, formulations thereof that are added in small amounts (parts per million, ppm) to a corrosive environment in order to delay or decrease the corrosion process of the surface to be protected.

Due to the fact that equipment constructed with materials resistant to corrosion is very expensive, it is common to use corrosion inhibitors as a practical, economical and simple alternative.

A recent study in the United States indicated that their industries spent about $\$ 276$ billion/year (on what?) and around 900 million/year on about 200 million tons of CIs. This market is shared by about $40 \%$ of inorganic inhibitors such as sulfonates and phosphonates (for cooling towers) and $60 \%$ of organic inhibitors, for example amines, cyclic amines, quaternary amidoamines, dietilamines, imidazolines and fatty acids, which are primarily used as CIs in the Petroleum Industry, in the production of gas, refineries, oil pipelines and products [26].

The CI formulations generally are made up of one or more active ingredients and suitable vehicles (other additives and solvents) that encourage compatibility with the environment and make viable the active transport to the area to be protected (metal surface).

The properties that must be met by a CI are [27, 28]:

a. Capability of reducing corrosion rates.

b. The active principle of the CI must be in contact with the metal to be protected.

c. Must not have side effects.

Sometimes, two components or active ingredients in a formulation may have a higher efficiency when they are mixed than that obtained from the sum of the efficiencies that are 
obtained when they are used individually at the same concentration. This effect is known as synergy or synergistic effect and is widely used in the formulation of CIs.

The CI can be classified in different ways $[29,30]$.

According to the specific application within the oil refining processes:

a. Embedding inhibitors.

b. Blistering inhibitors.

c. High temperature inhibitors.

d. Inhibitors for acidic media.

e. Inhibitors for basic media.

f. Inhibitors for cooling water.

The CI can also be classified according to the type of material to be protected. In the oil refining processes, CIs are of special interest for carbon steel, in which the major component is iron; and inhibitors for copper-zinc alloys (Admiralty), which are the most common materials used in the design of refineries.

CIs can be classified as anodic, which are those that inhibit oxidation of the metal; cathodic, which inhibit the reduction of oxygen; and mixed inhibitors, which inhibit both processes.

CIs can also be classified according to the type of compound that forms the active ingredient in the formulation as inorganic, organic and biocides.

\section{Inhibitor mechanism}

The action mechanisms of CIs are [31]:

- By adsorption, forming a film that is adsorbed onto the metal surface.

- By inducing the formation of corrosion products such as iron sulfide, which is a passivizing species.

- By changing media characteristics, producing precipitates that can be protective and eliminating or inactivating an aggressive constituent.

It is well known that organic molecules inhibit corrosion by adsorption, forming a barrier between the metal and the environment. Thus, the polar group of the molecule is directly attached to metal and the nonpolar end is oriented in a vertical direction to the metal surface, which repels corrosive species, thus establishing a barrier against chemical and electrochemical attack by fluids on the metallic surface (Figure 10). 


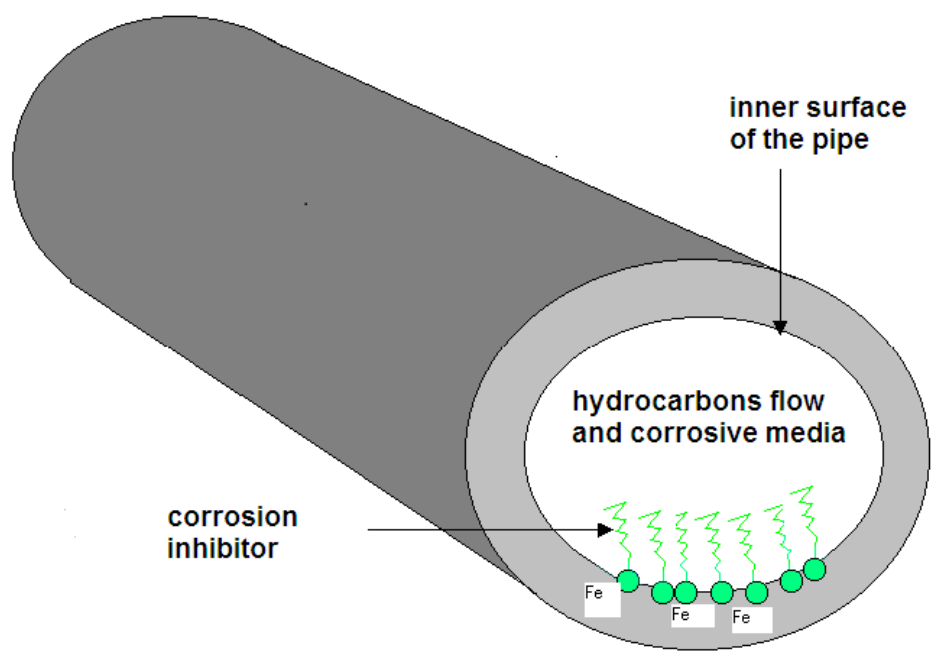

Figure 10. Representation of a $\mathrm{Cl}$ adsorbed into a metal surface.

An inhibitor may be effective in one system, while in another it is not, (Table 1); therefore, it is convenient to consider the following factors:

- Chemical structure of the inhibitor component.

- Chemical composition of the corrosive medium.

- Nature of the metal surface.

- Operating conditions (temperature, pressure, $\mathrm{pH}$, etc.).

- Thermal stability of the inhibitor. - Corrosion inhibitors have temperature limits above which lose their effectiveness because they suffer degradation of the containing components.

- Solubility of the inhibitor in the system. - The solubility of the inhibitor in the system is required to achieve optimum results in the metal surface protection; this depends on the length of the hydrocarbon chain.

- The addition of surfactants to enhance the dispersibility or solubility of inhibitors.

- Modification of the molecular structure of the inhibitor by ethoxylation to increase the polarity, and thus reach its solubility in the aqueous medium.

The main features of an inhibitor are:

- Ability to protect the metal surface.

- High activity to be used in small quantities (ppm). 
- Low cost compound(s).

- Inert characteristics to avoid altering a process.

- Easy handling and storage.

- Preferably with low toxicity.

- Non-contaminant.

- It should act as an emulsifier.

- It should act as a foaming agent.

\section{Environmentally Friendly Corrosion Inhibitors (EFCIs)}

In recent years, owing to the growing interest and attention of the world towards the protection of the environment and the hazardous effects of using chemicals on the ecological balance, the traditional approach on CIs has gradually changed. As mentioned before, for an inhibitor to be an effective protector against metal corrosion, it should be readily adsorbed on the metal surface through either physisorption or chemisorption processes. Either of these adsorption processes depends primarily on the physicochemical properties of the inhibitor group such as functional groups, electronic density at the donor atom, molecular structure, etc. For instance, organic molecules, which have had a wide applicability and that have been extensively studied and used as CIs, often contain nitrogen, oxygen, and sulfur atoms, as well as multiple bonds in their molecules.

\subsection{Evaluating the toxicity of CIs}

Aspects to be taken into account in the development of CIs are their toxicity and impact on environmental pollution of both the active and other components of the formulation.

The European Economic Community assigned the Paris Commission (PARCOM) the task of providing guidance for environmental pollution control, protection of the ecosystems and the evaluation of the toxicity of raw materials and industrial waste products.

The PARCOM Environmental has developed a standardized test that covers three aspects:

1. Toxicity: This must be determined for the formulation as a whole.

Toxicity should be measured by using either the 50 Lethal Concentration (LC50), which is the concentration at which $50 \%$ of the test organisms are killed, or the EC50, which is the concentration that can cause an adverse organism affection, e.g. the concentration decreases the emission intensity of luminescent bacteria by $50 \%$ or the concentration decreases the growth or average weight of certain microorganisms by $50 \%$.

The toxicity degree may be classified according to the LC50 value, where these categories are described in Table 2 [32]. 


\begin{tabular}{|c|c|}
\hline CATEGORY & LC $_{50}$ \\
\hline Supertoxic & $5 \mathrm{mg} / \mathrm{kg}$ of weight or less \\
\hline Extremely toxic & $5-50 \mathrm{mg} / \mathrm{kg}$ \\
\hline Highly toxic & $50-500 \mathrm{mg} / \mathrm{kg}$ \\
\hline Moderately toxic & $0.5-5 \mathrm{~g} / \mathrm{kg}$ \\
\hline Slightly toxic & $5-15 \mathrm{~g} / \mathrm{kg}$ \\
\hline Practically non-toxic & More than $15 \mathrm{~g} / \mathrm{kg}$ \\
\hline
\end{tabular}

Table 2. Classification of the toxicity of chemical compounds according to the LC50.

Toxicity testing for corrosion inhibitors to be measured in at least three different species and for the optimum established time, (Table 3).

\begin{tabular}{|l|c|c|}
\hline \multicolumn{1}{|c|}{ Group } & Preferred especies & Test \\
\hline Algae & Skeletonema costatum & 72-hour EC \\
\hline Fish and crustaceans & Acartia tonsa & 48 -hour $\mathrm{LC}_{50}$ \\
\hline Parasites & Coropium voluntaros & 10-day $\mathrm{LC}_{50}$ \\
\hline
\end{tabular}

Table 3. Parameters for developing standardized toxicity tests.

2. Biodegradation: It must be determined for all the formulation components.

This test measures the persistence in the environment of the formulation components. The standard test that should be applied is the marine OECD. The allowable limit is more than $60 \%$ after 28 days.

3. Bioaccumulation: This test measures the level of product buildup in the body. Bioaccumulation is measured by the partition coefficient (eq. 1), as this parameter can be correlated with the cell interface/water ratio.

$$
\mathrm{Po} / \mathrm{w}=\frac{\text { concentration in octanol }}{\text { concentration in water }}
$$

This means that the greater the partition coefficient, the more likely it is that the compound passes through the cell membrane, being bioaccumulated.

EFCIs can be arbitrarily divided into two categories: natural products and low toxicity synthetic products. In this last category, special attention has been paid to a new class of low toxicity organic compounds known as ionic liquids.

There are a few studies where CIs are evaluated according to the methodology described in this section and designed as low toxicity CIs or EFCIs. Most of the inhibitors that receive this 
rating are based on products that are derived from natural sources that are considered as compatible, biodegradable or environmentally friendly, although strictly, their toxicity has not been assessed by following the testing protocol presented above.

In the next sections, a brief overview of recent research works on the study of EFCIs with particular interest in those with potential applications in the Petroleum Industry is given.

\subsection{Natural products as EFCIs}

Natural products have been studied extensively as corrosion inhibitors both in product mixtures extracted from natural sources such as plants or essentially pure products derived from animals or plants (i.e. vitamins and aminoacids).

From the economic and environmental view points, plant extracts are an excellent alternative as inhibitors because of their availability and biodegradability. These extracts can be obtained in a simple way and purification methods are not required. The extracts are generally obtained from cheap solvents that are widely available, at a low cost and with low toxicity; the aqueous extract is more relieved, but due to the low solubility of many natural products in water, common ethanol extracts are also obtained. These extracts contain a variety of natural products such as essential oils, tannins, pigments, steroids, terpenes, flavones and flavonoids, among other well-known active substances used as CIs. In general, these compounds present conjugated aromatic structures, long aliphatic chains such as nitrogen, sulfur, and oxygen heteroatoms with free electron pairs that are available to form bonds with the metal surface; in most cases, they act synergistically to exhibit good efficiency regarding the corrosion protection. This can be demonstrated in the case of Ginkgo biloba in which the main components (flavonoids and terpenoids) have been identified (Figure 11). This extract has demonstrated excellent efficiency as CI with potential applications in the Oil Industry concerning the corrosion inhibition of Q235A steel. The antibacterial activity of the extracts against oil field microorganisms (SRB, IB and TGB) has also been proved [33].

The main disadvantage of using plant materials as CIs is their frequently low stability, they are readily biodegradable; however, this disadvantage can be minimized or avoided by adding biocides such as $N$-cetyl- $N, N, N$-trimethyl ammonium bromide.

In the last years, Umoren and Obot's research group has published several papers about the evaluations of plant extracts as CIs, for example, Phyllanthus amarus [34], Pachylobus edulis [35], Raphia hookeri [36], Ipomoea involcrata [37] and Spondias mombin L. [38].

Recently, this group described the inhibitive action of ethanolic extracts from leaves of Chlomolaena Odorata L. (LECO) as eco-friendly CI of acid corrosion of aluminum in $2 \mathrm{M} \mathrm{HCl}$, using hydrogen evolution and thermometric techniques [39]; and more recently, for corrosion of mild steel in $\mathrm{H}_{2} \mathrm{SO}_{4}$ solutions [40]. In this last paper, the obtained results showed that LECO functioned as a $\mathrm{CI}$ and its efficacy increased with the extract concentration, but decreased with temperature. At a concentration as low as $5 \% \mathrm{v} / \mathrm{v}$ of the extract, the inhibitory efficiency reached about $95 \%$ at $303 \mathrm{~K}$, and $89 \%$ at $333 \mathrm{~K}$. 
<smiles>O=c1c(O)c(-c2ccc(O)c(O)c2)oc2cc(O)cc(O)c12</smiles>

Quercetin

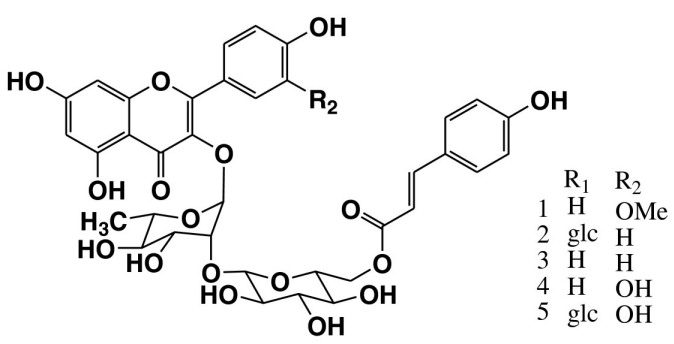<smiles>COc1cc(-c2oc3cc(O)cc(O)c3c(=O)c2O)ccc1O</smiles>

Isorhamnetin

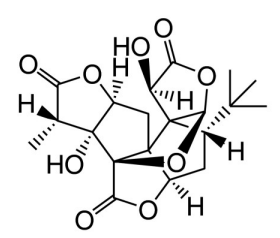

Ginkgolide A<smiles>[R2]c1cc(-c2oc3cc(O)cc(O)c3c(=O)c2OCC)ccc1O</smiles>

$\mathrm{R}_{1} \quad \mathrm{R}_{2}$

6 -rha(2-1)-glc $\mathrm{H}$

7 -rha(2-1)-glc OMe

8 -rha(2-1)-glc $\mathrm{OH}$

9 rutinose

10 rutinose

11 rutinose

$12 \mathrm{glc}$

$\mathrm{OMe}$

$13 \mathrm{glc}$

$\mathrm{OH}$
$\mathrm{H}$

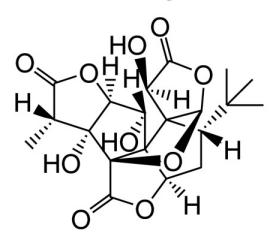

Ginkgolide B

Figure 11. Structures of flavonoids and terpenoids found in Ginkgo biloba.

In another interesting work, this group showed the excellent inhibitory properties of Coconut coir dust extract (CCDE) as corrosion inhibitor of aluminum in $1 \mathrm{M} \mathrm{HCl}$, using weight loss and hydrogen evolution techniques at 30 and $60^{\circ} \mathrm{C}$ by monitoring the volume of evolved hydrogen gas at fixed time intervals (Figure 12). The representative plots of the volume of the evolved hydrogen gas as a function of the reaction time at 30 and $60^{\circ} \mathrm{C}$ for $\mathrm{Al}$ in $1 \mathrm{M} \mathrm{HCl}$, in the absence and presence of different concentrations of the CCDE, showed a remarkable increase in the volume of evolved $\mathrm{H}_{2}$ gas in the blank acid solution at both studied temperatures. As for the introduction of CCDE into the corrosive medium, it is seen that there is a considerable reduction in the volume of evolved hydrogen gas, suggesting that the CCDE components were adsorbed onto the metal surface, and blocked the electrochemical reaction efficiently by decreasing the available surface area [41]. 

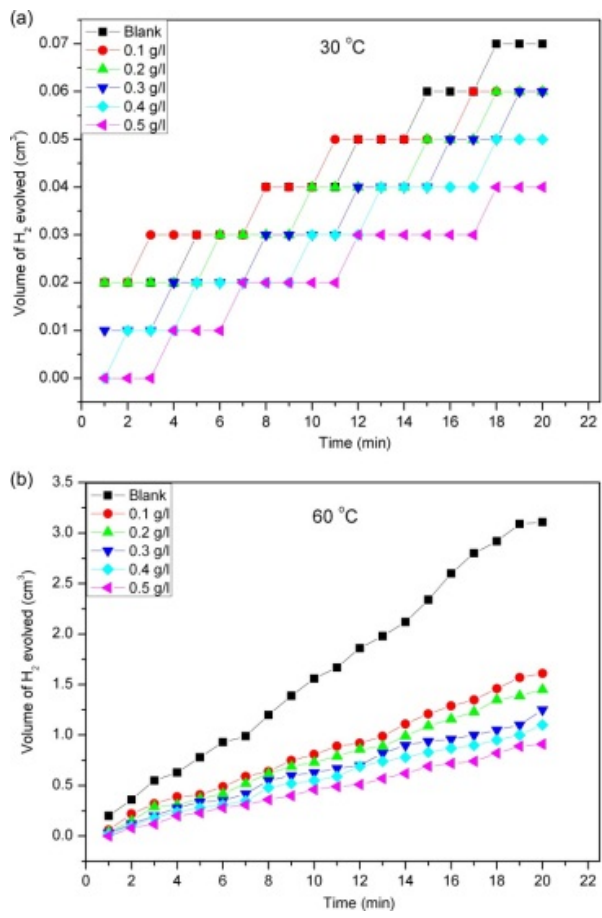

Figure 12. Plot of evolved hydrogen volume against time for $\mathrm{Al}$ in $1 \mathrm{M} \mathrm{HCl}$ with and without different CCDE concentrations at (a) $30^{\circ} \mathrm{C}$ and (b) $60^{\circ} \mathrm{C}$. Reprinted from ref. [41]

Table 4 summarizes examples of natural extracts that have been evaluated in recent years as CIs $[42,43]$.

In the category of natural isolated products, aminoacids and their derivatives are some of the most studied pure compounds as EFCI. These natural compounds and derivatives have been used as good CIs for mild steel [75-80], carbon steel [81-83], stainless steel [84], iron [85], nickel [86], copper [87-91], aluminum [92], and alloys [93] and [94] in different aggressive solutions.

Very recently, the inhibitory properties of l-histidine on the corrosion of carbon steel in weak acid media containing acetic acid/sodium acetat have been tested. The inhibition efficiencies obtained by weight loss measurements are in good agreement with values given by the Tafel method and electrochemical impedance spectroscopy. The adsorption of 1-histidine obeys the Langmuir isotherm; the negative values of the Gibbs energy indicate the nature of the interactions between the inhibitor molecules and metal surface. Further, the inhibition effect was studied by using scanning electron microscopy and energy dispersive $\mathrm{X}$-ray analysis [95].

Other low-toxicity natural products including natural polymers described as CIs are summarized in Table 5. 


\begin{tabular}{|c|c|c|}
\hline Reference & Natural product source & Metal or Alloy protected \\
\hline [44] & $\begin{array}{l}\text { Polysaccharide (galactomannan) extracted from the } \\
\text { endosperms of some leguminosae plants as coffee beans and } \\
\text { chickpeas. }\end{array}$ & Concrete Armor Protection \\
\hline$[45]$ & Chenopodium ambrorsioides extract & Carbon steel \\
\hline$[46]$ & Ethanolic Extracts from Seeds of Garcinia kola & Mild steel \\
\hline [47] & Musa acuminata flower extract & Mild steel \\
\hline [48] & Cannabis plant extract & Copper \\
\hline [49] & Mexican Argemona plant extract & Mild steel \\
\hline$[50]$ & Lavandula dentata aqueous extract & Mild steel \\
\hline$[51]$ & Aframomum melegueta extracts & Mild steel \\
\hline [52] & Osmanthus fragran leaves extract & Carbon steel \\
\hline$[53]$ & $\begin{array}{l}\text { Neolamarckia cadamba extract (bark, leaves) and pure alkaloid } \\
\text { (3 beta-isodihydrocadambine) }\end{array}$ & Mild steel \\
\hline$[54]$ & Murraya koenigii leaves extract & Mild steel \\
\hline$[55]$ & Berberine extracted from Coptis chinensis & Mild steel \\
\hline$[56]$ & Hibiscus sabdariffa extract & Mild steel \\
\hline [57] & Artemisia oil & Steel \\
\hline [58] & Ethanolic extract of Musa species & Mild steel \\
\hline [59] & Aqueous extract of Hibiscus rosa-sinensis Linn & Carbon steel \\
\hline$[60,61]$ & Opuntia-Ficus-Indica (Nopal) & Aluminum and Steel \\
\hline [62] & Tobacco extract & Steel and Aluminum \\
\hline [63] & Aqueous extract of rhizome powder (Curcuma longa $L$ ) & Carbon steel \\
\hline$[64]$ & Onion juice & Zinc \\
\hline$[65]$ & Vernonia amygdalina & Aluminum \\
\hline$[66]$ & Mangrove tannin & Copper \\
\hline [67] & Punica granatum extract & Brass \\
\hline$[68]$ & Phoenix dactylifera L. fruit juice & Aluminum \\
\hline [69] & Rain water containing garlic extract & Aluminum \\
\hline$[70]$ & Polyphenols extracted from olive mill wastewater & Carbon steel \\
\hline [71] & Morinda tinctoria leaves extract & Mild steel \\
\hline [72] & Aqueous extract of Creosote Bush (Larrea tridentata) leaves & Carbon steel \\
\hline [73] & Prosopis Laevigata & Aluminum \\
\hline [74] & Lanvandula stoekas leaves extract & Stainless steel \\
\hline
\end{tabular}

Table 4. Extracts of natural products described as Cls. 


\begin{tabular}{|c|c|c|}
\hline Reference & Natural product & Metal or Alloy protected \\
\hline [96] & caffeine & Carbon steel \\
\hline [97] & caffeine & Copper \\
\hline [98] & Purine and adenine & Copper \\
\hline [99] & Vitamin $\mathrm{B}_{1}$ & AISI 4130 steel alloy \\
\hline$[100]$ & Vitamin $B_{1}$ & Copper \\
\hline$[101,102]$ & Vitamin C & Steel \\
\hline [103] & Pteroyl-L-glutamic acid (Vitamin M) & $\begin{array}{c}\text { Scale inhibitor for oil wells of carbonate } \\
\text { reservoir }\end{array}$ \\
\hline [104] & Citric acid & Aluminum \\
\hline [105] & Benzoic acid & Iron and aluminum \\
\hline$[106]$ & Vitamin $B_{1}, B_{6}$ and $C$ & Nickel \\
\hline [107] & Peptin & Aluminum \\
\hline [108] & lignin terpolymer & Aluminum \\
\hline [109] & cassava starches & Aluminum \\
\hline [110] & Carrageenan (polysacharide polymer) & Aluminum \\
\hline [111] & Chitosan & Steel \\
\hline
\end{tabular}

Table 5. Natural products, including natural polymers described as Cls.

\subsection{Synthetic compounds as EFCIs}

Numerous inorganic and organic compounds have been reported as CIs for metals in different media, but the toxic nature of many of them limits their application. In the last decades, much attention has been focused on the need to design and develop synthetic non-toxic corrosion organic inhibitor to replace toxic ones for a sustainable development, for example, 12aminododecanoic acid has been described as "green" CI for carbon steel [112], while imidazole derivatives [113] and guanidine [114] have been reported as non-toxic CIs for copper in acid media.

Several human drugs, including diuretics and barbiturates have shown good performance as CIs of metals in acid media [115-128]. In this sense, two well-known diuretics, Furosemide and Torsemide were recently evaluated as CIs of mild steel in hydrochloric acid medium. From the two inhibitors, Torsemide performance is superior to that of Furosemide due to its high electron density, which favors its adsorption on the metal surface. Polarization studies revealed that the inhibiting action of the compounds is under mixed control. The free adsorption energy and the temperature influence on the adsorption of inhibitors onto a mild steel surface have been reported. The adsorption of the compounds was found to obey the Langmuir adsorption isotherm. The inhibition and formation mechanisms of the Fe-inhibitor complex were confirmed by FT-IR and UV-visible absorption spectral analysis. The scanning electron microsco- 
py (SEM) and atomic force microscopy (AFM) results established the formation of a protective layer on the mild steel surface. Quantum chemical calculations were applied to correlate the inhibition performance of inhibitors with their electronic structural parameters [129].

In 2011 the application of drugs as promising novel EFCIs was reviewed [130].

Several synthetic polymers have also been designed as efficient EFCIs for carbon steel in alkaline solution [131] and for calcium carbonate scale inhibitor for cooling water [132, 133].

Ionic liquids (ILs) deserve particular attention due to the rapid grown in the number of applications in the Oil Industry [134], and particularly within the topic of synthetic EFCIs, these have shown an effective performance as inhibitors of various metals and alloys [135-151].

ILs are ionic compounds, showing anisotropic molecular shape; their structure contains both organic and inorganic type components with various functional groups. They offer novel physical and chemical properties like low toxicity, high chemical stability, low vapour pressure and high electrical conductivity [152-157].

Quite a number of ILs do behave not only as green solvents suitable for the electrochemical devices and methods but also as unique and robust electrolytes with high stability Also, these compounds present structure properties suitable to be absorbed on metal surfaces and some derivatives of these families have proved that they can act as EFCIs in acid and basic corrosive environments.

Likhanova et al. have published a paper about the inhibitory action of 1,3-dioctadecylimidazolium bromide ( $\operatorname{ImDC}_{18} \mathrm{Br}$ ), $\mathrm{N}$-octadecylpyridinium bromide $\left(\mathrm{PyC} \mathrm{C}_{18} \mathrm{Br}\right.$ ) in $1 \mathrm{M} \mathrm{H}_{2} \mathrm{SO}_{4}$ on mild steel at room temperature. The effect of the concentration of inhibitor compounds was investigated by electrochemical tests, whereas the surface analysis was performed at $100 \mathrm{ppm}$ for both compounds. In the case of $\operatorname{ImDC}_{18} \mathrm{Br}$, corrosion products were additionally studied by X-ray diffraction and Mössbauer spectroscopy. The results revealed that ILs act as corrosion inhibitors with $82-88 \%$ at $100 \mathrm{ppm}$ to protect the mild steel corrosion in the aqueous solution of sulfuric acid; their efficiencies are increased with the inhibitor concentration in the range 10-100 ppm range. SEM-EDX, XRD and Mössbauer analysis indicated the presence of carbon species and iron sulfates in the presence of ILs; whereas corrosion products such as iron oxyhydroxides were present in the absence of the ILs; this behavior was described by the proposed corrosion inhibition mechanism [158].

The same research group published a related paper in 2011 where five imidazolium-type ILs containing N1-vynil and N3-long alkyl saturated chains as cation and bromide as anion were synthesized under microwave irradiation and evaluated as CIs for acid environment. Weight loss and electrochemical polarization techniques were used to test the inhibitory properties of these compounds in AISI 1018 carbon steel immersed in $1.0 \mathrm{MH}_{2} \mathrm{SO}_{4}$. All the studied ILs showed inhibitory properties dependent on the chain length linked to N3. The highest efficiency of IL4 was confirmed by Scanning Electron Microscopy (SEM)/Energy-Dispersive X-ray spectroscopy (EDX) and AtomicForce Microscopy (AFM) images of film formation. SEM revealed revealed that the surface morphology was strongly damaged in the $\mathrm{CI}$ absence, but in the presence of 100 ppm of CI, damage was considerably diminished, which confirmed the high efficiency of 1-Vinyl-3-octadecylimidazolium bromide at this concentration (Figure 13) [159]. 


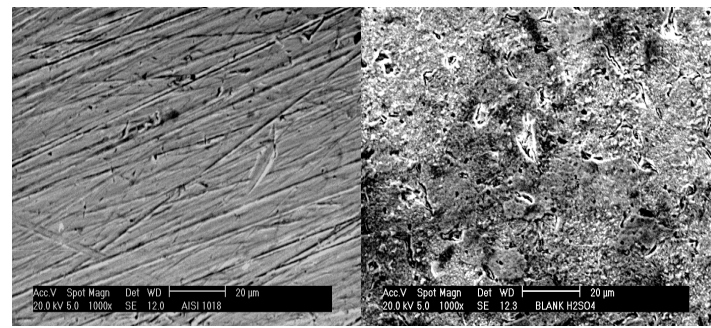

(a) (b)

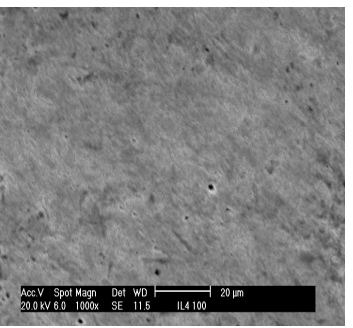

(c)

Figure 13. SEM images (1000X) of metallic surfaces: (a) after polishing, (b) after 6 hours of immersion in the corrosive medium without inhibitor, (c) after 6 hours of immersion in the corrosive medium with 100 ppm of 1-Vinyl-3-octadecylimidazolium bromide. Reprinted (adapted) with permission from ref. [159]. Copyright (2011) American Chemical Society.

ILs have also been employed to prepare a thin protective aluminum layer on carbon steel surface by electroreduction and electrodeposition of 1-butyl-3methyl-imidazolium chloroaluminate $\left(\mathrm{AlCl}_{3} /[\mathrm{BMIM}] \mathrm{Cl}\right)[160,161]$.

Recently, the inhibition effect of 1-ethyl-3-methylimidazolium dicyanamide (EMID) against steel corrosion was investigated. In this study, EMID was evaluated as corrosion inhibitor for steel and then it was fixed in the polymer film. EMID is able to assemble a protective film on steel surface, under acidic conditions. The results of SEM analysis and potentiodynamic studies also showed that this inhibitor film is stable around corrosion potential. The steel surface becomes positively charged during inhibitor adsorption and the anionic part of EMID plays the major adsorption role. The inhibitor was fixed within polypyrrole coating on steel, and it was shown that this addition could improve the protection efficiency of the coating [162].

Junguroya et al. reported another recent interesting result. They found that water containing traces of hydrophobic ILs ([BMIM]Cl and [BMIM]NTf ${ }_{2}$ ) exhibit unusual corrosion inhibiting behavior by protecting metal copper and nickel from electrochemical corrosion under aerobic conditions. The anodic dissolution of a copper electrode results in the formation of $\mathrm{Cu}$ (I) species. The simultaneous re-electrodeposition of nanocrystalline copper on the cathode occurred without additives to the resulting electrolyte [163]. Also, the high-temperature corrosion behavior of several metals $\left(\mathrm{Ni}, \mathrm{Cu}\right.$, and alloys) in [BMIM]NTf $\mathrm{Bn}_{2}$ under aerobic conditions has been investigated by electrochemical methods [164].

The development of EFCIs based on organic rare earth compounds such as salycilates, phosphates, chromates and cinnamates was reviewed in 2011 [165].

\section{Conclusions}

As it has been seen through this chapter, corrosion inhibitors are economically feasible to mitigate the problems caused by corrosion. Environmental regulations in industrialized countries are increasing the pressure to eliminate, in the short term, a number of compounds 
widely used in industrial to prevent corrosion. A number of alternatives of EFCIs are currently emerging, oriented towards minimizing environmental impact providing effective corrosion inhibition. EFCIs include natural products, extracts from plants, and synthetic low-toxicity compounds. We hope that these products will be able to replace, in the near future, the toxic commercial products that are still being used by many industries worldwide.

\section{Author details}

Rafael Martinez Palou${ }^{1}$, Octavio Olivares-Xomelt ${ }^{2}$ and Natalya V. Likhanova ${ }^{1}$

1 Instituto Mexicano del Petróleo, Dirección de Investigación y Posgrado, México, México

2 Benemérita Universidad Autónoma de Puebla, Facultad de Ingeniería Química, Puebla, México

\section{References}

[1] Sastri VS. Green Corrosion Inhibitors. Theory and Practice. John Wiley \& Sons: Hoboken, NJ; 1998.

[2] Sastri VS. Corrosion Inhibitors Principles and Applications. John Wiley \& Sons: New York; 1998.

[3] Bethencourt M. Lanthanide compounds as environmental friendly corrosion inhibitors of aluminium alloys: a review. Corrosion Science 1998;40(11) 1803-1819.

[4] Olivares-Xometl O, Likhanova NV, Gómez B, Navarrete J, Llanos-Serrano ME, Arce E, Hallen JM. Electrochemical and XPS studies of decylamides of alpha-amino acids adsorption on carbon steel in acidic environment. Applied Surface Science 2006;252(6) 2894-2909.

[5] Olivares-Xometl O, Likhanova NV, Domínguez-Aguilar MA, Arce E, Dorante H, Arellanes-Lozada P. Synthesis and corrosion inhibition of alpha-amino acids alkylamides for mild steel in acidic environment. Material Chemistry Physics 2008;110(2-3) 344-351.

[6] Abd El-Maksoud SA, Fouda AS. Some pyridine derivatives as corrosion inhibitors for carbon steel in acidic medium. Material Chemistry Physics 2005;93: 84-90.

[7] Ergun Ü, Yüzer D, Emregül KC. The inhibitory effect of bis-2,6-(3,5-dimethylpyrazolyl)pyridine on the corrosion behaviour of mild steel in $\mathrm{HCl}$ solution. Material Chemistry Physics. 2008;109: 492-499. 
[8] Noor EA. Evaluation of inhibitive action of some quaternary N-heterocyclic compounds on the corrosion of $\mathrm{Al}-\mathrm{Cu}$ alloy in hydrochloric acid. Material Chemistry Physics 2009;114: 533-541.

[9] Cruz J, Martínez-Palou R, Genesca J, García-Ochoa, E. Experimental and theoretical study of 1-(2-ethylamino)-2-methylimidazoline as an inhibitor of carbon steel corrosion in acid media. Journal of Electroanalytical Chemistry 2004;566(1) 111-121.

[10] Martinez-Palou R, Rivera J, Zepeda LG, Rodríguez AN, Hernandez MA, Marín-Cruz J, Estrada A. Evaluation of corrosion inhibitors synthesized from fatty acids and fatty alcohols isolated from sugar cane wax. Corrosion 2004;60(5) 465-470.

[11] Olivares-Xometl O, Likhanova NV, Martínez-Palou R, Dominguez-Aguilar MA. Electrochemistry and XPS study of an imidazoline as corrosion inhibitor of mild steel in an acidic environment. Materials and Corrosion 2009;60(1) 14-21.

[12] Liu FG, Du M, Zhang J, Qiu M. Electrochemical behavior of Q235 steel in saltwater saturated with carbon dioxide based on new imidazoline derivative inhibitor. Corrosion Science 2009;51(1) 102-109.

[13] Likhanova NV, Martínez-Palou R, Veloz MA, Matías DJ, Reyes-Cruz VE, OlivaresXometl O. Microwave-assisted synthesis of 2-(2-pyridyl)azoles. Study of their corrosion inhibiting properties. Journal of Heterocyclic Chemistry 2007;44(1) 145-153.

[14] Popova A, Christov M, Zwetanova A. Effect of the molecular structure on the inhibitor properties of azoles on mild steel corrosion in $1 \mathrm{M}$ hydrochloric acid. Corrosion Science 2007;49(5) 2131-2143.

[15] Antonijevic MM, Milic SM, Petrovic MB. Films formed on copper surface in chloride media in the presence of azoles. Corrosion Science 2009;51(6) 1228-1237.

[16] Tallman DE, Spinks G, Dominis A, Wallace GG. Electroactive conducting polymers for corrosion control Part 1. General introduction and a review of non-ferrous metals. Journal of Solid States Electrochemistry 2002;6(2) 73-84. b) Spinks G, Dominis A, Wallace GG, Tallman DE. Electroactive conducting polymers for corrosion control Part 2. Ferrous metals. Journal of Solid States Electrochemistry 2002;6(2) 85-100.

[17] Chemical Inhibitors for Corrosion Control. The Royal Society of Chemistry; 1990.

[18] The Multimedia Corrosion Guide [CD-ROM]. INSA, Lyon; 2013.

[19] Marcus P, Maurice V, Strehblow HH. Localized corrosion (pitting): A model of passivity breakdown including the role of the oxide layer nanostructure. Corrosion Science 2008;50(9) 2698-2704.

[20] Levy AV. The erosion-corrosion behavior of protective coatings. Surface and Coatings Technology. 2002;36(1-2) 387-406.

[21] Sieradzki K, Newman RC. Stress-corrosion cracking. Journal of Physics and Chemistry of Solids. 1987;48(11) 1101-1113. 
[22] Song G, Johannesson B, Hapugoda S, StJohn D. Galvanic corrosion of magnesium alloy AZ91D in contact with an aluminium alloy, steel and zinc. Corrosion Science 2004;46(4) 955-977.

[23] Al-Hashem A, Riad W. The role of microstructure of nickel-aluminium-bronze alloy on its cavitation corrosion behavior in natural seawater. Material Characterization 2002;48(1) 37-41. b) Neville A, McDougall BAB. Erosion-and cavitation-corrosion of titanium and its alloys. Wear 2001;250(1-12) 726-735.

[24] González JL, Ramirez R, Hallen JM, Guzman RA. Hydrogen-Induced Crack Growth Rate in Steel Plates Exposed to Sour Environments. Corrosion 1997;53(12) 935-943.

[25] Revie W, Uhlig HH. Corrosion and corrosion control: An introduction to corrosion science and engineering. Wiley-Interscience: New York; 2008. https://www.corrosioncost.com (accessed 1 august 2013), Ref. 2, p537-566.

[26] Distasio JI. Chemical for Oil Field Operations. Ed. Noyes Data Corp., New Jersey, E.U; 1981.

[27] Salensky G. Organic Corrosion Inhibitors. In: Salensky, G. (ed.) Handbook of Coatings Additives; 1987. p340-356. Ref. 2, p681-688.

[28] Corrosion Mechanisms in Theory and Practice, 3rd Ed. Marcus P (Ed.), Taylor and Francis Group, CRC, Boca Raton; 2012. Ref. 2, p885-894.

[29] Chen G, Zhang M, Zhao J, Zhou R, Meng Z, Zhang Z. Investigation of Ginkgo biloba leave extracts as corrosion and oil field microorganism inhibitors. Chemistry Central Journal 2013;7(Article Number: 83).

[30] Okafor PO, Ikpi ME, Uwah IE, Ebenso EE, Ekpe UJ, Umoren SA. Inhibitory action of Phyllanthus amarus extracts on the corrosion of mild steel in acidic media. Corrosion Science 2008;50(8) 2310-2317.

[31] Umoren SA, Ekanem UF. Inhibition of Mild Steel Corrosion in H2SO4 using Exudate Gum from Pachylobus Edulis and synergistic Potassium Halides Additives. Chemical Engineering Communications 2010;197(10) 1339-1356.

[32] Umoren SA,Obot IB, Ebenso EE,Obi-Egbedi NO. The Inhibition of aluminium corrosion in hydrochloric acid solution by exudate gum from Raphia hookeri. Desalination 2009; 247(1-3) 561-572.

[33] Obot IB, Obi-Egbedi NO, Umoren SA, Ebenso EE. Synergistic and Antagonistic Effects of Anions and Ipomoea invulcrata as Green Corrosion Inhibitor for Aluminium Dissolution in Acidic Medium. Internation Journal of Electrochemical Science 2010;5(7) 994-1007.

[34] Obi-Egbedi NO, Obot IB, Obot IB, Umoren SA. Spondias mombin L. as a green corrosion inhibitor for aluminium in sulphuric acid: Correlation between inhibitive effect 
and electronic properties of extracts major constituents using density functional theory. Arabian Journal of Chemistry 2012;5(3) 361-373.

[35] Obot IB,Obi-Egbedi NO. An interesting and efficient green corrosion inhibitor for aluminium from extracts of Chlomolaena odorata L. in acidic solution. Journal of Applied Electrochemistry 2010;40(11) 1977-1984.

[36] Obot IB, Ebenso EE, Gasem ZM. Eco-friendly Corrosion Inhibitors: Adsorption and Inhibitive Action of Ethanol Extracts of Chlomolaena Odorata L. for the Corrosion of Mild Steel in H2SO4 Solutions. Journal of Electrochemical Science 2012;7(3) 1997-2008.

[37] Umoren SA, Eduok UM, Israel AU, Obot IB, Solomon MM. Coconut coir dust extract: a novel eco-friendly corrosion inhibitor for $\mathrm{Al}$ in $\mathrm{HCl}$ solutions. Green Chemistry Letters and Reviews 2012;5(3) 303-313.

[38] Rani BEA, Basu BBJ. Green inhibitors for corrosion protection of metals and alloys: An overview. International Journal of Corrosion 2012; articule ID: 380217.

[39] Rajendran S, Sri VG, Arockiaselvi J, Amalraj AJ. Corrosion inhibition by plant extracts - an overview. Bulletin of Electrochemistry 2005;21(8) 367-377.

[40] Lame A, Kokalari E, Jano A. Use of Green Inhibitors for Concrete Armor Protection Against H2SO4 Corrosion. Asian Journal of Chemistry 2013;25(7) 4017-4021.

[41] Belkhaouda, M.; Bammou, L.; Zarrouk, A, Salghi R, Ebenso EE, Zarrok H, Hammouti B, Bazzi L, Warad I. Inhibition of C-steel Corrosion in Hydrochloric Solution with Chenopodium Ambrorsioides Extract. International Journal of Electrochemical Science 2013;8(5) 7425-7436.

[42] Ikeuba AI, Okafor PC, Ekpe UJ, Ebenso EE. Alkaloid and Non-Alkaloid Ethanolic Extracts from Seeds of Garcinia Kola as Green Corrosion Inhibitors of Mild Steel in H2SO4 Solution. International Journal of Electrochemical Science 2013;8(5) 7455-7467.

[43] Gunavathy N, Murugavel SC. Studies on Corrosion Inhibition of Musa acuminata Flower Extract on Mild Steel in Acid Medium. Asian Journal of Chemistry 2013;25(5) 2483-2490.

[44] Abd-El-Nabey BA, Abdel-Gaber AM, Ali M. El. Said, Khamis E, El-Housseiny S. Inhibitive Action of Cannabis Plant Extract on the Corrosion of Copper in $0.5 \mathrm{M}$ H2SO4. International Journal of Electrochemical Science 2013; 8(5) 7124-7137.

[45] Ji G, Shukla S, Dwivedi P, Sundaram S, Prakash R. Inhibitive Effect of Argemone mexicana Plant Extract on Acid Corrosion of Mild Steel. Industrial \& Engineering Chemistry Research 2011;50(21) 11954-11959.

[46] Zarrok H, Zarrouk A, Salghi R, Ebn Touhami M, Oudda H, Hammouti B, Touir R, Bentiss F, Al-Deyab SS. The Anti-Corrosion Behavior of Lavandula dentata Aqueous 
Extract on Mild Steel in 1M HCl. International Journal of Electrochemical Science 2013;8(4) 6005-6013.

[47] Oguzie EE, Iheabunike ZO, Oguzie KL, Ogukwe CE, Chidiebere MA, Enenebeaku CK, Akalezi CO. Corrosion Inhibiting Effect of Aframomum melegueta Extracts and Adsorption Characteristics of the Active Constituents on Mild Steel in Acidic Media. Journal of Dispersion Science and Technology 2013;34(4) 516-527.

[48] Li LJ, Zhang XP, Lei JL, He JX, Zhang ST, Pan FS. Adsorption and corrosion inhibition of Osmanthus fragran leaves extract on carbon steel. Corrosion Science 2012;63: 82-90.

[49] Raja PB, Qureshi AK, Rahim AA, Osman H, Awang K. Neolamarckia cadamba alkaloids as eco-friendly corrosion inhibitors for mild steel in $1 \mathrm{M} \mathrm{HCl}$ media. Corrosion Science 2013;69: 292-301.

[50] Quraishi MA, Singh A, Singh VK, Yadav DY, Singh AK. Green approach to corrosion inhibition of mild steel in hydrochloric acid and sulphuric acid solutions by the extract of Murraya koenigii leaves. Material Chemitry Physics 2010;122(1) 114-122.

[51] Li Y, Zhao P, Liang Q, Hou BR. Berberine as a natural source inhibitor for mild steel in $1 \mathrm{M} \mathrm{H}_{2} \mathrm{SO}_{4}$. Applied Surface Science 2005;252(5) 1245-1253.

[52] Oguzie EE. Corrosion inhibitive effect and adsorption behaviour of Hibiscus sabdariffa extract on mild steel in acidic media. Portugaliae Electrochimica Acta 2008;26(3) 303-314.

[53] Bouyanzer A, Hammouti B. A study of anti-corrosive effects of Artemisia oil on steel. Pigment and Resin Technology. 2004;33(5) 287-292.

[54] Eddy NO, Odoemelam SA, Odiongenyi AO. Ethanol extract of musa species peels as a green corrosion inhibitor for mild steel: Kinetics, adsorption and thermody-namic considerations. Electronic Journal of Environmental, Agricultural and Food Chemistry $2008 ; 8(4) 243-255$.

[55] Anuradha K, Vimala R, Narayanasamy B, Selvi J, Arockia RS. Corrosion inhibition of carbon steel in low chloride media by an aqueous extract of hibiscus rosa-sinensis Linn. Chemistry Engineering Communication 2008;195(3) 352-366.

[56] El-Etre AY. Inhibition of aluminum corrosion using Opuntia extract. Corrosion Science 2003;45(11) 2485-2495.

[57] Torres-Acosta AA. Opuntia-Ficus-Indica (Nopal) mucilage as a steel corrosion inhibitor in alkaline media. Journal of Applied Eclectrochemistry 2007;37(7) 835-841.

[58] Davis GD. The Use of Extracts of Tobacco Plants as Corrosion Inhibitors. http:// www.electrochem.Org/dl/ma/ 202/pdfs/0340.PDF.

[59] Rajendran S, Shanmugapriya S, Rajalakshmi T, Raj AJA. Corrosion inhibition by an aqueous extract of rhizome powder. Corrosion 2005;61(7) 685-692. 
[60] El-Etre AY. Natural onion juice as inhibitors for zinc corrosion. Bulletin of Electrochemistry 2006;22(2) 75-80.

[61] Popoola API, Fayomi OSI. Electrochemical Study of Zinc Plate in Acid Medium: Inhibitory Effect of Bitter Leaf (vernonia Amygdalina). International Journal of Electrochemistry Science 2011;6(10) 4581-4592.

[62] Shah AM, Rahim AA, Hamid SA, Yahya S. Green Inhibitors for Copper Corrosion by Mangrove Tannin. International Journal of Electrochemistry Science 2013;8(2) 2140-2153.

[63] Deepa PR, Selvaraj S. Inhibitive and adsorption properties of punica granatum extract on brass in acid media. Journal of Phytology. 2010;2(11) 58-64.

[64] Gerengi H. Anticorrosive Properties of Date Palm (Phoenix dactylifera L.) Fruit Juice on 7075 Type Aluminum Alloy in $3.5 \% \mathrm{NaCl}$ Solution. Industrial \& Engineering Chemistry Research 2012;51(39) 12835-12843.

[65] Priya SL, Chitra A, Rajendra S, Anuradha, K. Corrosion behaviour of aluminium in rain water containing garlic extract. Surface Engineering 2005;21(3) 229-231.

[66] Larif M, Elmidaoui A, Zarrouk A, Zarrok H, Salghi R, Hammouti B, Oudda H, Bentiss F. An investigation of carbon steel corrosion inhibition in hydrochloric acid medium by an environmentally friendly green inhibitor. Research on Chemical Intermediates 2013;39(6) 2663-2677.

[67] Krishnaveni K, Ravichandran J, Selvaraj A. Effect of Morinda Tinctoria Leaves Extract on the Corrosion Inhibition of Mild Steel in Acid Medium. Acta Metallurgica Sinica-English Letters 2013;26(3) 321-327.

[68] García-Inzunza R, Valdez-Salas B, Schorr Wiener M, Beltran M, Koytchev RZ, Stilianova M, Ramos-Irigoyen R, Vargas-Osuna L, Terrazas-Gaynor J. Aqueous Extract of Creosote Bush (Larrea tridentata) Leaves as Green Inhibitor for Carbon Steel in Hydrochloric Acid Solution. International Journal of Electrochemistry Science 2013;8(5) 6864-6877.

[69] Ramirez-Arteaga, M.; Valladares, M. G.; Gonzalez Rodriguez, J. G. Use of Prosopis Laevigata as a Corrosion Inhibitor for $\mathrm{Al}$ in H2SO4. International Journal of Electrochemistry Science 2013; 8(5) 6864-6877.

[70] Boudalia M, Guenbour A, Bellaouchou A, Laqhaili A, Mousaddak M, Hakiki A, Hammouti B, Ebenso EE. Corrosion Inhibition of Organic Oil Extract of Leaves Of Lanvandula Stoekas on Stainless Steel in Concentrated Phosphoric Acid International Journal of Electrochemistry Science 2013;8(5) 7414-7424.

[71] Fu J, Li S, Wang Y, Cao L, Lu L. Computational and electrochemical studies of some amino acid compounds as corrosion inhibitors for mild steel in hydrochloric acid solution. Journal of Material Science 2010;45(22) 6255-6265. 
[72] Ashassi-Sorkhabi H, Majidi MR, Seyyedi K. Investigation of inhibition effect of some amino acids against steel corrosion in $\mathrm{HCl}$ solution. Applied Surface Science 2004;225(1-4) 176-185.

[73] Olivares-Xometl O, Likhanova NV, Dominguez-Aguilar MA, Arce E. Synthesis and corrosion inhibition of $\alpha$-amino acids alkylamides for mild steel in acidic environment. Material Chemistry Physics 2008;110(2-3) 344-351.

[74] Morad MS. Corrosion inhibition of mild steel in sulfamic acid solution by S-containing amino acids. Journal of Applied Electrochemistry 2008;38(11) 1509-1518.

[75] Oezcan M. AC impedance measurements of cysteine adsorption at mild steel/sulphuric acid interface as corrosion inhibitor. J. Solid State Electrochemistry 2008;12(12) 1653-1661.

[76] Morad MS. Effect of amino acids containing sulfur on the corrosion of mild steel in phosphoric acid solutions containing $\mathrm{Cl}^{-}, \mathrm{F}^{-}$and $\mathrm{Fe}^{3+}$ ions: behaviour under polarization condition. Journal of Applied Electrochemistry 2005;35(9) 889-895.

[77] Olivares O, Likhanova NV, Gómez B, Navarrete J, Llanos-Serrano ME, Arce E, Hallen JM. Electrochemical and XPS studies of decylamides of $\alpha$-amino acids adsorption on carbon steel in acidic environment. Applied Surface Science 2006;252(6) 2894-2909.

[78] Fu J, Li S, Cao L, Wang Y, Yan L, Lu L. L-Tryptophan as green corrosion inhibitor for low carbon steel in hydrochloric acid solution. Journal of Material Science 2010;45(4) 979-986.

[79] Cui R, Gu N, Li C. Polyaspartic acid as a green corrosion inhibitor for carbon steel. Materials and Corrosion-Werkstoffe und Korrosion 2011; 62(4) 362-369.

[80] Silva AB, Agostinho SML, Barcia OE, Cordeiro GGO, D'Elia E. The effect of cysteine on the corrosion of $304 \mathrm{~L}$ stainless steel in sulphuric acid. Corrosion Science 2006;48(11) 3668-3674

[81] Amin MA, Khaled KF, Mohsen Q, Arida HA. A study of the inhibition of iron corrosion in $\mathrm{HCl}$ solutions by some amino acids. Corrosion Science 2010;52(5) 1684-1695.

[82] Gece G, Bilgic S. A theoretical study on the inhibition efficiencies of some amino acids as corrosion inhibitors of nickel. Corrosion Science 2010;52(10) 3435-3443.

[83] Moretti G, Guidi F. Tryptophan as copper corrosion inhibitor in $0.5 \mathrm{M}$ aerated sulfuric acid. Corrosion Science 2002;44(9) 1995-2011.

[84] Zhang D, Gao L-X, Zhou G-D. Inhibition of copper corrosion in aerated hydrochloric acid solution by amino-acid compounds. Journal of Applied Electrochemistry 2005;35(11) 1081-1085.

[85] Radovanovic MB, Petrovic MB, Simonovic AT, Milic SM, Antonijevic MM. Cysteine as a green corrosion inhibitor for Cu37Zn brass in neutral and weakly alkaline sulphate solutions. Environmental Science and Pollution Research 2013;20(7) 4370-4381. 
[86] Zhang DQ, Cai QR, He XM, Ga LX, Zhou GD. Inhibition effect of some amino acidsof copper corrosion in aerated hydrochloric acid solution by amino-acid compounds. Material Chemistry Physics 2008;112(2) 353-358.

[87] Barouni K, Bazzi L, Salghi R, Milhit M, Hammouti B, Albourine A, El Issami S. Some amino acids as corrosion inhibitors for copper in nitric acid solution. Material Letters 2008;62(19) 3325-3327.

[88] Ashassi-Sorkhabi H, Ghasemi Z, Seifzadeh D. The inhibition effect of some amino acids towards the corrosion of aluminum in $1 \mathrm{M} \mathrm{HCl}+1 \mathrm{M} \mathrm{H}_{2} \mathrm{SO}_{4}$ solution. Applied Surface Science 2005;249: 408-418.

[89] Ghasemi Z, Tizpar A. The inhibition effect of some amino acids towards $\mathrm{Pb}-\mathrm{Sb}-\mathrm{Se}-$ As alloy corrosion in sulfuric acid solution. Applied Surface Science 2006;252(10) 3667-3672.

[90] Kiani MA, Mousavi MF, Ghasemi S, Shamsipur M, Kazemi SH. Inhibitory effect of some amino acids on corrosion of $\mathrm{Pb}-\mathrm{Ca}-\mathrm{Sn}$ alloy in sulfuric acid solution. Corrosion Science 2008;50, 1035-1045.

[91] Bobina M, Kellenberger A Millet J.-P., Cornelia M, Nicolae V. Corrosion resistance of carbon steel in weak acid solutions in the presence of L-histidine as corrosion inhibitor. Corrosion Science 2013;69: 389-395.

[92] Rajendran S, Amalraj AJ, Joice MJ, Anthony N, Trivedi DC, Sundaravadivelu M. Corrosion inhibition by the caffeine - Zn2+ system. Corrosion Reviews 2004;22: 233-248.

[93] Fallavena T, Antonow M, Goncalves RS. Caffeine as non-toxic corrosion inhibitor for copper in aqueous solutions of potassium nitrate. Applied Surface Science 2006;253(2) 566-571.

[94] Scendo M. Inhibition of copper corrosion in sodium nitrate solutions with nontoxic inhibitors. Corrosion Science 2008;50(6) 1584-1592.

[95] Hoseinzadeh AR, Danaee I, Maddahy MH. Thermodynamic and Adsorption Behaviour of Vitamin B1 as a Corrosion Inhibitor for AISI 4130 Steel Alloy in HCl Solution. International Journal of Research in Physical Chemistry \& Chemical Physics 2013;227(4) 403-417.

[96] Abiola OK, John MO, Asekunowo PO, Okafor PC, James OO. 3-[(4-amino-2-methyl-5-pyrimidinyl) methyl]-5-(2-hydroxyethyl)-4-methyl thiazolium chloride hydrochloride as green corrosion inhibitor of copper in HNO3 solution and its adsorption characteristics. Green Chemistry Letters and Reviews 2011;4(3) 273-279.

[97] Fuchs-Godec R, Pavlovic MG, Tomic MV.The Inhibitive Effect of Vitamin-C on the Corrosive Performance of Steel in $\mathrm{HCl}$ Solutions. International Journal of Electrochemical Science 2013;8(1) 1511-1519. 
[98] Valek L, Martinez S, Mikulic D Brnardic I. The inhibition activity of ascorbic acid towards corrosion of steel in alkaline media containing chloride ions. Corrosion Science 2008;50(9) 2705-2709.

[99] Kumar T, Vishwanatham S, Kundu SS. A laboratory study on pteroyl-L-glutamic acid as a scale prevention inhibitor of calcium carbonate in aqueous solution of synthetic produced water. Journal of Petroleum Science and Engineering 2010;71(1-2) $1-7$.

[100] Solmaz R, Kardas G, Yazici B, Erbil M. Citric acid as natural corrosion inhibitor for aluminium protection. Corrosion Engineering Science and Technology. 2008;43(2) 186-191.

[101] Sibel Z. The effects of benzoic acid in chloride solutions on the corrosion of iron and aluminum. Turkish Journal of Chemistry 2002;26(3) 403-408.

[102] Malhotra S, Singh G. Vitamins: potential inhibitors for nickel in acidic media. Surface Engineering 2005;21(3) 187-192.

[103] Fare MM, Maayta AK, Al-Qudah MM. Pectin as promising green corrosion inhibitor of aluminum in hydrochloric acid solution. Corrosion Science 2012;60: 112-117.

[104] Ren Y, Luo Y, Zhang K, Zhu G, Tan X. Lignin terpolymer for corrosion inhibition of mild steel in 10\% hydrochloric acid medium. Corrosion Science 2008;50: 3147-3153.

[105] Bello M, Ochoa N, Balsamo V, Lopez-Carrasquero F, Coll S, Monsalve A. González G. Modified cassava starches as corrosion inhibitors of carbon steel: An electrochemical and morphological approach Carbohydrate Polymers 2010;82(3) 561-568.

[106] Fares MM, Maayta AK, Al-Mustafa JA. Corrosion inhibition of iota-carragenan natural polymer on aluminum in presence of zwitterion mediator in $\mathrm{HCl}$ media. Corrosion Science 2012;65: 223-230.

[107] Zheludkevich ML, Tedim J, Freire CSR, Fernandes SCM, Kallip S, Lisenkov A, Gandini A, Ferreira MGS. Self-healing protective coatings with "green" chitosan based pre-layer reservoir of corrosion inhibitor. Journal of Material Chemistry 2011;21(13) 4805-4812.

[108] Ghareba S, Omanovic S. Interaction of 12-aminododecanoic acid with a carbon steel surface. Towards the development of 'green' corrosion inhibitors. Corrosion Science 2010;52(6) 2104-2113.

[109] Stupnisek-Lisac E, Gazivoda A, Madzarac M. Evaluation of non-toxic corrosion inhibitors for copper in sulphuric acid. Electrochimica Acta 2002;47(26) 4189-4194.

[110] Khaled KF. Adsorption and inhibitive properties of a new synthesized guanidine derivative on corrosion of copper in 0.5 M H2SO4. Applied Surface Science 2008;255(5) 1811-1888.

[111] Obot IB, Ebenso EE, Obi-Egbedi NO, Afolabi AS, Gasem, ZM. Experimental and theoretical investigations of adsorption characteristics of itraconazole as green corrosion 
inhibitor at a mild steel/hydrochloric acid interface. Research on Chemical Intermediates 2012;38(8) 1761-1779.

[112] Ahamad I, Quraishi MA. Mebendazole: New and efficient corrosion inhibitor for mild steel in acid medium Corrosion Science 2010;52(2) 651-656.

[113] Shukla, S. K.; Singh, A. K.; Ahamad, I.; Quraishi, M. A.Streptomycin: A commercially available drug as corrosion inhibitor for mild steel in hydrochloric acid solution Mater. Lett. 2009;63(9-10) 819-822.

[114] Verma C, Quraishi MA, Ebenso EE. Electrochemical Studies of 2-amino-1, 9-dihydro-9-((2-hydroxyethoxy) methyl)-6H-purin-6-one as Green Corrosion Inhibitor for Mild Steel in 1.0 M Hydrochloric Acid Solution. International Journal of Electrochemical Science 2013;8(5) 7401-7413.

[115] Oezcan M, Solmaz R, Kardas G, Dehri, I. Adsorption properties of barbiturates as green corrosion inhibitors on mild steel in phosphoric acid. Colloids and Sufaces A. 2008;24(3-4) 57-63.

[116] Kardas G, Solmaz R. Electrochemical investigation of barbiturates as green corrosion inhibitors for mild steel protection. Corrosion Reviews 2006;24(3-4) 151-171.

[117] Prabhu RA, Shanbhag AV, Venkatesha TV. Influence of tramadol [2-[(dimethylamino)methyl]-1-(3-methoxyphenyl)cyclohexanolhydrate] on corrosion inhibition of mild steel in acidic media. Journal of Applied Electrochemistry 2007;37(4) 491-497.

[118] El-Naggar M. Corrosion inhibition of mild steel in acidic medium by some sulfa drugs compounds. Corrosion Science 2007;49(5) 2226-2236.

[119] Morad MS. Inhibition of iron, corrosion in acid solutions by Cefatrexyl: Behaviour near and at the corrosion potential Corrosion Science 2008;50(2) 436-448.

[120] Singh AK, Quraishi MA. Effect of Cefazolin on the corrosion of mild steel in $\mathrm{HCl}$ solution. Corrosion Science 2010;52(1) 152-160.

[121] Shukla, SK, Quraishi MA. Cefotaxime sodium: A new and efficient corrosion inhibitor for mild steel in hydrochloric acid solution Corrosion Science 2009;51(5) 1007-1011.

[122] Obot IB, Obi-Egbedi NO, Umoren SA. Antifungal drugs as corrosion inhibitors for aluminium in 0.1 M HCl. Corrosion Science 2009;51(8) 1868-1875.

[123] Ahamad I, Prasad R, Quraishi MA. Inhibition of mild steel corrosion in acid solution by Pheniramine drug. Experimental and theoretical study Corrosion Science 2010;52(9) 3033-3041.

[124] Singh AK, Quraishi MA. Inhibitive effect of diethylcarbamazine on the corrosion of mild steel in hydrochloric acid. Corrosion Science 2010; 52(4) 1529-1535. 
[125] Kumar SH, Karthikeyan S. Torsemide and Furosemide as Green Inhibitors for the Corrosion of Mild Steel in Hydrochloric Acid Medium. Industrial \& Engineering Chemistry Research 2013;52(22) 7457-7469.

[126] Gece G. Drugs: A review of promising novel corrosion inhibitors. Corrosion Science 2011;53(12) 3873-3898.

[127] Al Juhaiman LA, Abu Mustafa A, Mekhamer WK. Polyvinyl pyrrolidone as a green corrosion inhibitor for carbon steel in alkaline solutions containing NaCl. Anti-Corrosion Methods and Materials 2013;60(1) 28-36.

[128] Liu GQ, Huang JY, Zhou YM, Yao QZ, Yang Y, Ling L, Wang HC, Wu WD, Sun W, $\mathrm{Hu} \mathrm{ZH}$. Fluorescent-tagged acrylic acid-allylpolyethoxy carboxylate copolymer as a green inhibitor for calcium phosphate in industrial cooling systems. Designed Monomer Polymers 2012;16(1) 89-98.

[129] Liu G, Huang J, Zhou Y, Yao Q, Wang H, Ling L, Zhang P, Cao K, Liu Y, Wu W, Sun,W. Carboxylate-Terminated Double-Hydrophilic Block Copolymer Containing Fluorescent Groups: An Effective and Environmentally Friendly Inhibitor for Calcium Carbonate Scales. International Journal of Polymeric Materials and Biopolymeric Materials 2013; 62(13) 678-685.

[130] Martínez-Palou R., Flores P. Perspectives of Ionic Liquids for Clean Oilfield Technologies. In Kokorin A (ed.) Perspectives of Ionic Liquids for Clean Oilfield Technologies. Rijeka: InTech; 2011. p567-530. Available from http://www.intechopen.com/ books/ionic-liquids-theory-properties-new-approaches.

[131] Khaled KF. The inhibition of benzimidazole derivatives on corrosion of iron in $1 \mathrm{M}$ $\mathrm{HCl}$ solutions. Electrochimica Acta 2003;48: 2493-2503.

[132] Zhou X, Yang HY, Wang FH. [BMIM]BF4 ionic liquids as effective inhibitor for carbon steel in alkaline chloride solution. Electrochimica Acta 2011;56(11) 4268-4275.

[133] Cho E, Mun J, Chae OB, Kwon OM, Kim HT, Ryu JH, Kim YG, Oh SM. Corrosion/ passivation of aluminum current collector in bis(fluorosulfonyl) imide-based ionic liquid for lithium-ion batteries. Electrochemistry Communication 2012; 22: 1-3.

[134] Palomar ME, Olivares-Xometl O, Likhanova NV, Pérez-Navarrete JB. Imidazolium, Pyridinium and Dimethyl-Ethylbenzyl Ammonium Derived Compounds as Mixed Corrosion Inhibitors in Acidic Medium. Journal of Surfactants and Detergents. 2011; 14(2) 211-220.

[135] Gabler C, Tomastik C, Brenner J, Pisarova L, Derr N, Allmaier G. Corrosion properties of ammonium based ionic liquids evaluated by SEM-EDX, XPS and ICP-OES. Green Chemistry 2011;13(10) 2869-2877.

[136] Zhang QB, Hua YX. Corrosion inhibition of mild steel by alkylimidazolium ionic liquids in hydrochloric acid. Electrochimica Acta 2009;54(6) 1881-1887. 
[137] Zhang QB, Hua YX. Corrosion inhibition of aluminum in hydrochloric acid solution by alkylimidazolium ionic liquids. Material Chemistry and Physics 2009; 119(1-2) 57-64.

[138] Ashassi-Sorkhabi H, Es'haghi M. Corrosion inhibition of mild steel in acidic media by [BMIm]Br Ionic liquid. Material Chemistry and Physics 2009;114(1) 267-271.

[139] Perez-Navarrete JB, Olivares-Xometl CO, Likhanova NV. Adsorption and corrosion inhibition of amphiphilic compounds on steel pipeline grade API 5L X52 in sulphuric acid 1 M. Journal of Applied Electrochemistry 2010;40(9) 1605-1617

[140] Morad MS, Hermas AA, Obaid AY, Qusti, AH. Evaluation of some bipyridinium dihalides as inhibitors for low carbon steel corrosion in sulfuric acid solution. Journal of Applied Electrochemistry 2008;38(9) 1301-1311.

[141] Saleh MM, Atia AA. Effects of structure of the ionic head of cationic surfactant on its inhibition of acid corrosion of mild steel. Journal of Applied Electrochemistry 2006;36(8) 899-905.

[142] Wang H, Liu SQ, Huang KL, Liu Y, Li Z. Ethylbenzotriazolium Bromide Ionic Liquid: A New Water Soluble Inhibitor for Corrosion of Mild Steel in Acid Media. Asian Journal of Chemistry 2013;25(2) 954-956.

[143] Zarrouk A, Messali M, Zarrok, H, Salghi, R, Ali, A. Al-Sheikh, Hammouti, B, AlDeyab SS, Bentiss, F. Synthesis, Characterization and Comparative Study of New Functionalized Imidazolium-Based Ionic Liquids Derivatives Towards Corrosion of C38 Steel in Molar Hydrochloric Acid. International Journal of Electrochemical Science 2012;51(10) 13282-13299.

[144] Likhanova NV, Olivares-Xometl O, Guzmán-Lucero D, Domínguez-Aguilar MA, Nava N, Corrales-Luna M, Mendoza, M. C. Corrosion inhibition of carbon steel in acidic environment by imidazolium ionic liquids containing vinylhexafluorophosphate as anion International Journal of Electrochemistry Science 2011;6(109) 4514-4536.

[145] Qi-Bo Z, Yi-Xin H. Effect of alkylimidazolium ionic liquids on the corrosion inhibition of copper in sulfuric acid solution Acta Physico Chimica Sinica 2011;27(3) 655-663.

[146] Murulana LC, Singh, AK, Shukla, SK, Kabanda MM, Ebenso EE. Experimental and Quantum Chemical Studies of Some Bis(trifluoromethyl-sulfonyl) Imide Imidazolium-Based Ionic Liquids as Corrosion Inhibitors for Mild Steel in Hydrochloric Acid Solution. Industrial \& Engineering Chemical Research 2012;51(40) 13282-13299.

[147] Rogers RD, Seddon KR., editors. Ionic Liquids: Industrial Applications for Green Chemistry. ACS: Boston; 2002.

[148] Rogers RD, Seddon KR., editors. Ionic Liquids as Green Solvent: Progress and Prospects. ACS: Boston; 2003. 
[149] Wasserscheid P., Keim W., editors. Ionic Liquids in Synthesis, Wiley-VCH: Wenheim; 2004.

[150] Martínez-Palou R. (2006). Química en Microondas. (E-book). CEM Publishing: Matthew, NC; 2006. p131-154.

[151] Martínez-Palou R. (2007). Ionic liquids and Microwave-assisted Organic Synthesis. A "Green" and Synergic Couple. Journal of Mexican Chemical Society 2007;51(4) 252-264.

[152] Martínez-Palou R. Microwave-assisted synthesis using ionic liquids. Molecular Diversity 2010;14(4) 3-25.

[153] Freemantle M. An Introduction to Ionic Liquids. RSC Press. Cambridge, UK; 2009.

[154] Likhanova NV, Domínguez-Aguilar MA, Olivares-Xometl O, Nava-Entzana N, Arce E, Dorante $\mathrm{H}$. The effect of ionic liquids with imidazolium and pyridinium cations on the corrosion inhibition of mild steel in acidic environment. Corrosion Science 2010;52(6) 2088-2097.

[155] Guzmán-Lucero D, Olivares-Xometl O, Martínez-Palou R, Likhanova NV, Domínguez-Aguilar MA, Garibay-Febles V. Synthesis of Selected Vinylimidazolium Ionic Liquids and Their Effectiveness as Corrosion Inhibitors for Carbon Steel in Aqueous Sulfuric Acid. Industrial \& Engineering Chemical Research 2011;50(12) 7129-7140.

[156] Caporali S, Fossati A, Lavacchi A, Perissi I, Tolstogouzovm A, Bardi U. Aluminium electroplated from ionic liquids as protective coating against steel corrosion. Corrosion Science 2008;50(2) 534-539.

[157] Yue GK, Lu XM, Zhu Y, Hang XP, Zhang SJ. Surface morphology, crystal structure and orientation of aluminium coatings electrodeposited on mild steel in ionic liquid. Chemical Engineering Journal 2009;147(1) 79-86.

[158] Tuken T, Demir F, Kicir N, Sigircik G, Erbil M. Inhibition effect of 1-ethyl-3-methylimidazolium dicyanamide against steel corrosion. Corrosion Science 2012;59: 110-118.

[159] Lebedeva O, Junguroya G, Zakharov A, Kultin, D, Chernikova E, Kustov, L. Water as an Inhibitor of Metal Corosion in Hydrophobic Ionic Liquids. Journal of Physical Chemistry C 2012;116(42) 22526-22531

[160] Perissi I, Bardi U, Caporali S, Lavacchi A. High temperature corrosion properties of ionic liquids. Corrosion Science 2006;48(9) 2349-2362.

[161] Forsyth M, Seter M, Hinton B, Deacon G, Junk P. New “Green Corrosion Inhibitors" Based on Rare Earth Compounds. Austrlian Journal of Chemistry 2011;64(6) 812-819. 
